\title{
THE LOAD-BEARING CAPACITY OF TIMBER-GLASS COMPOSITE I-BEAMS MADE WITH POLYURETHANE ADHESIVES
}

\author{
Konrad RODACKI ${ }^{1}$ \\ Cracow University of Technology, Kraków, Poland
}

\begin{abstract}
This article discusses the issue of composite timber-glass I-beams, which are an interesting alternative for load-bearing beams of ceilings and roofs. The reasoning behind the use of timber-glass I-beams is the combination of the best features of both materials this enables the creation of particularly safe beams with regard to structural stability and post-breakage load capacity. Due to the significant differences between the bonding surfaces of timber and glass, a study on the adhesion of various adhesives to both surfaces is presented at the beginning of the paper. After examination, two adhesives were selected for offering the best performance when used with composite beams. The beams were investigated using a four-point bending test under quasi-static loading.
\end{abstract}

Keywords: timber-glass I-beams, polyurethane adhesive, innovative composite structures

\section{INTRODUCTION}

For about two decades, there has been increasing interest in the use of glass as a structural support material. This tendency is easy to understand because of the fascination of users and architects for transparent support elements as these make the buildings seem lighter and more impressive. Due to their growing popularity, more and more research projects relating of all kinds of structural glass elements can be found in literature - in these projects, glass is usually fused with other

\footnotetext{
${ }^{1}$ Corresponding author: Cracow University of Technology, Department of Civil Engineering. Warszawska st 24, 31-155 Kraków, Poland, e-mail: konrad.rodacki@gmai.com, tel.+48126282301
} 
materials. Composite timber-glass I-beams are one such type of element (Fig. 1). These composite beams enable us to maximise the strongest properties of both materials: for glass, it is its high stiffness and compressive strength; for timber, its high ductility, its ability to plasticise and the ease with which it can be worked. The connection of these two materials is achieved by the adhesive layer. The radically different nature of the load nature and the required bond rigidity are the main problems that arise during the selection of the adhesive. The best adhesives for static loads are those with high rigidity to ensure full fusion, and for dynamic loads (multiple-variable or seismic), adhesives with low rigidity that protect the glass from damage are better.
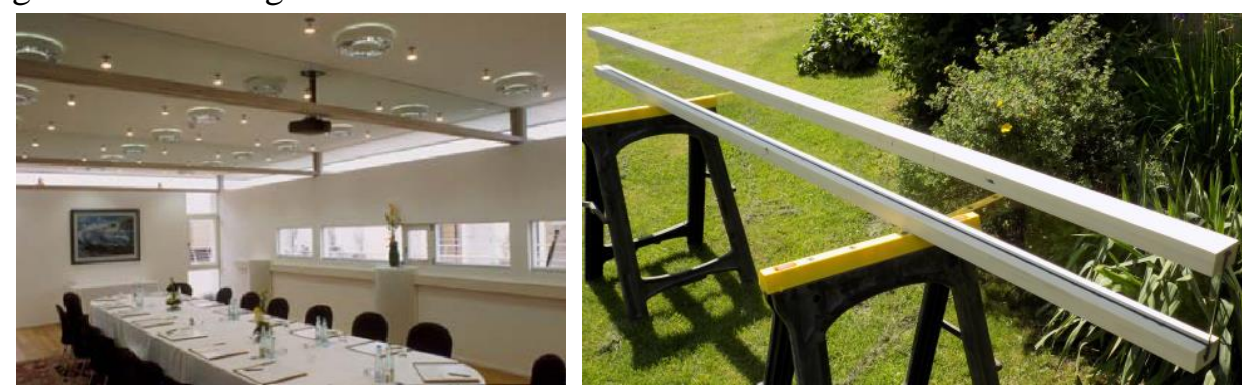

Fig. 1. Flat roof structure in the Palafitte Hotel, Switzerland [1] (left), timber-glass beam prepared for own test (right)

\section{REVIEW OF PREVIOUS RESEARCH ON COMPOSITE TIMBER-GLASS I-BEAMS}

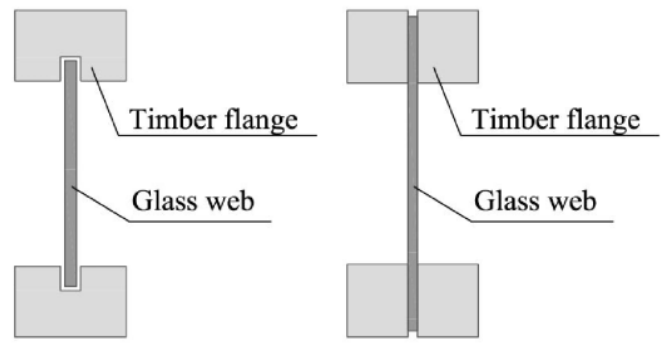

Fig. 2. Composite beam made by bond glass web into the grooves in timber flanges [5] (left), composite beam made as glass pane with bonded timber strips [3] (right)

The investigation of composite timber-glass I-beams has been carried out by several authors [1-15], these studies differ from each other by:

- the manner of beam assembly - glass bonded into a groove in a solid flange or timber strips bonded to each side of the glass web (Fig. 2); 
- the type of used glass - beams made with float glass (annealed), heatstrengthened glass, fully-tempered glass and laminated on PVB film glass webs,

- the type of flange material - softwood timber was usually used, but LVL flanges were also constructed;

- the scale of the test elements.

All the above-mentioned publications were discussed extensively in publications $[16,17]$ - only the most important conclusions are presented in this paper.
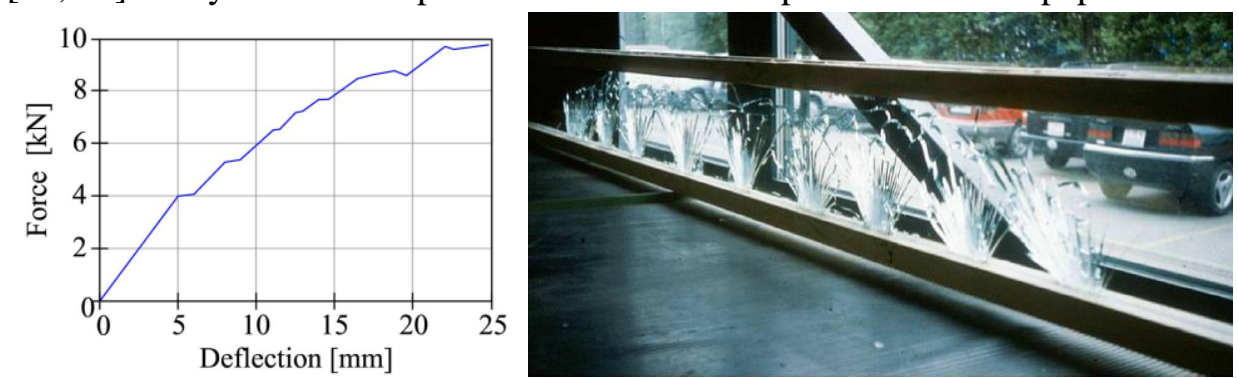

Fig. 3. Relationship between deflection and force applied to timber-glass I-beam (left), failed timber-glass I-beam (right) [3]

All of the mentioned studies were based on quasi-static loading elements in a fourpoint bending test, up to the point of beam failure. In all the conducted studies of beams that had webs made with float glass (annealed), two main features of the structure were observed: uniform spacing between the glass cracks (Fig. 3); large post-breakage capacity reaching up to $200 \%$ of the load value causing the first crack in the glass (Fig. 3). The use of float glass for this type of beams ensures that the rigidity of the element is maintained, even after web cracking. The beam rigidity is maintained by large glass pieces stacking and further transfer of shear forces. Timber provides ductility and creates a 'bridge' for the glass cracks similar to concrete reinforcement. In all studies in which the web was made with float glass (annealed), composite timber-glass I-beams eventually failed as a result of tension flange failure (Fig. 4). Beams with webs made with heatstrengthened and fully-tempered glass do not have such a feature and the first crack in the glass web caused simultaneous beam failure.

During other investigations, Cruz and Pequeno [5] observed that for less rigid adhesive joints (polymer), the distribution of cracks in the glass web is more uniform and the jumping on the load-displacement curve is smoother. It can be concluded that fully rigid connections between timber and glass are the most dangerous in the case of static loads because they present the most rupture nature of failure - there is no post-breakage capacity observed. 


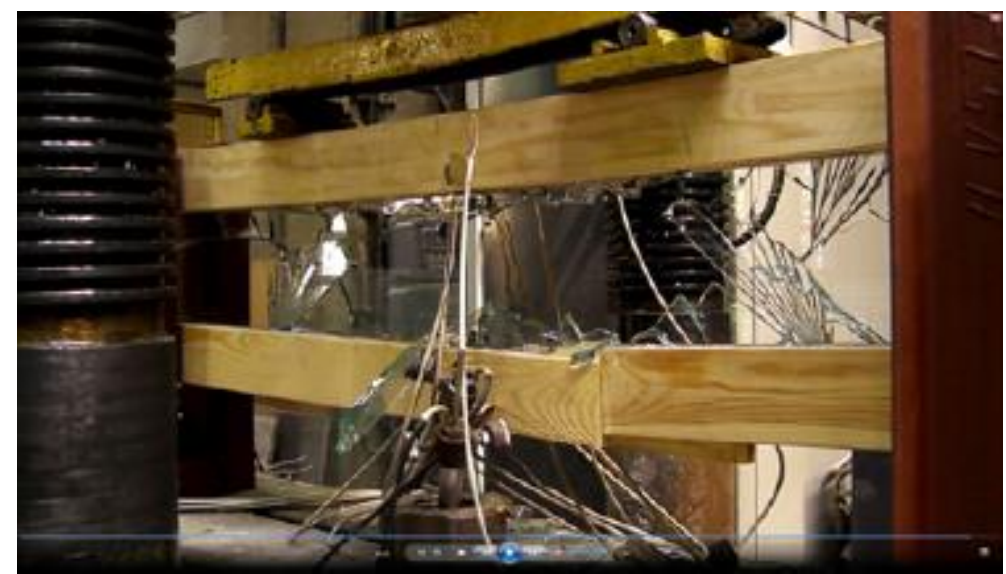

Fig. 4. Failure of composite timber-glass I-beam through the tension fail of flange [10]

The manner of finishing the glass edges has a significant impact on the bending capacity of composite timber-glass I-beams - this is presented in studies [18, 19].

\section{PULL-OFF EXPERIMENTAL INVESTIGATION OF ADHESIVE CONNECTION}
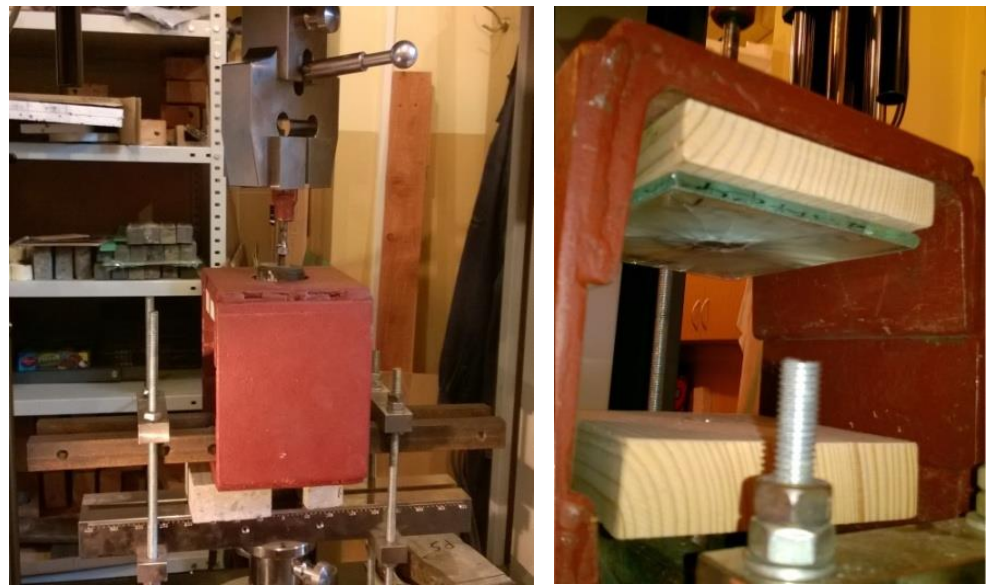

Fig. 5. Timber element (left) and glass element with timber spacer (right) mounted in the investigation tool during the pull-off tests

Due to the significant differences between the bonding surfaces of timber and glass, a study on the adhesion of various adhesives to both surface were performed as pull-off tests. In total, thirty-nine elements were studied; in the case of Sika®PM [20], Sika®PS [21] and Sika®PT [22] polyurethanes, adhesion to the glass and timber surfaces was dependent upon surface preparation. Detailed 
descriptions of the various types of items are shown in Table 1. Test elements were performed by bonding $50 \mathrm{~mm}$ diameter aluminium rollers to the investigated surfaces with a $2 \mathrm{~mm}$-thick adhesive layer. The investigated adhesives exhibit very strong adhesion to expanded aluminum surfaces $[23,24]$ and to steel and concrete surfaces $[25,26]$ - this suggests that the failure of the element will appear as a decohesion in the contact zone of the timber and glass or by failure in the adhesive-glass or adhesive-timber zone. Timber parts of the samples were made with structural class C22 fir timber according to [27], and the glass panes were made with float glass (annealed) in accordance with [28]. Some elements were primed with a dedicated polymer primer (Sika ${ }^{\circledR Z P}$ Primer) [29], as shown in Table 1. In addition, the surfaces of the glass elements were expanded by sandblasting.

Table 1. List of investigated pull-off elements divided into adhesive types, material of bonded elements and manner of surface finishing

\begin{tabular}{|c|c|c|c|c|}
\hline No & Adhesive type & Surface finishing & Amount & Element \\
\hline 1 & \multirow{5}{*}{$\begin{array}{c}\text { Poliurethane } \\
\text { Sika }{ }^{\circledR P S}\end{array}$} & glass blasted non-primed & 3 & PSN11-13 \\
\hline 2 & & glass plane non-primed & 3 & PSN21-23 \\
\hline 3 & & glass plane primed & 3 & PSP11-13 \\
\hline 4 & & timber primed & 4 & PSP01-04 \\
\hline 5 & & timber non-primed & 4 & PSN01-04 \\
\hline 6 & \multirow{3}{*}{$\begin{array}{c}\text { Poliurethane } \\
\text { Sika }{ }^{\circledR P T}\end{array}$} & glass blasted non-primed & 3 & PTN11-13 \\
\hline 7 & & timber primed & 4 & PTP01-04 \\
\hline 8 & & timber non-primed & 4 & PTN01-04 \\
\hline 9 & \multirow{3}{*}{$\begin{array}{c}\text { Poliurethane } \\
\text { Sika®PM }\end{array}$} & glass blasted non-primed & 3 & PMN11-13 \\
\hline 10 & & timber primed & 4 & PMP01-04 \\
\hline 11 & & timber non-primed & 4 & PMN01-04 \\
\hline
\end{tabular}

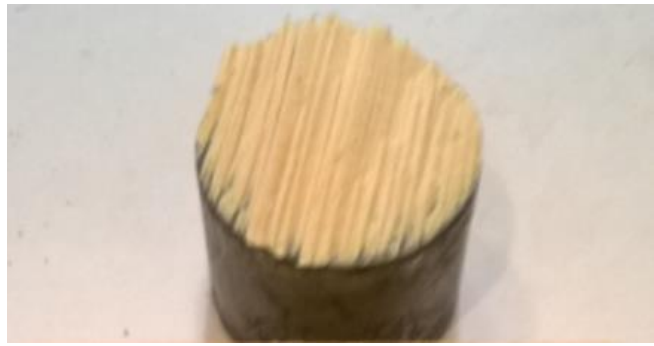

Fig. 6. Failed timber-adhesive joint after pull-off testing of Sika ${ }^{\circledR P S}$ polymer

The elements were mounted in the special steel element (Fig. 5), and to avoid stress concentrations, the glass elements were attached using a timber spacer. The 
head bolt was screwed into an aluminum cylinder to provide a hinge joint and placed in the upper jaws of the machine. The moisture content of the timber elements just after adhesive failure in the adhesive area was $11.2 \%$ on average. The element were loaded quasi-statically and continuously at a speed of $2 \mathrm{~mm} / \mathrm{min}$ until rupture occurred. The joint capacity of elements in which the adhesion to timber surface was investigated depends on the tension strength of timber transversal to grains (failure occurred in the timber) (Fig. 6), and in some cases, the adhesive layer (failure occurred in the adhesion zone). All connections made with the Sika ${ }^{\circledR P T}$ adhesive broke at a similar level of force regardless of whether the bonding surface was primed or not. For the Sika ${ }^{\circledR P S}$ polymer, it can be concluded that surface priming improved polymer adhesion strength to the bonding surface by approximately $10 \%$. In the case of the Sika ${ }^{\circledR P M}$ polymer, the influence of timber surface priming on the joint capacity was not determinable. The graphs in Fig. 7 show the force-displacement dependence for investigated elements bonded with the Sika ${ }^{\circledR P S}$ polymer. As can be observed, in general, the joints broke rapidly during the pull-off test, and the joint behaviour under loading could be described by a linear function for all of the investigated polymers.

For the elements for which the adhesion to the glass surface was investigated, the capacity of the joint was determined by the adhesive-glass zone in the vast majority or cases. Only in elements made with the Sika®PS polymer and glass surface priming with Sika ${ }^{\circledR} Z P$ Primer it was impossible to achieve the peel adhesion capacity of the pull-off element because the failure occured first in glass pane due to bending (Fig. 8). Although the strength of Sika ${ }^{\circledR P T}$ adhesive was the greatest through all the investigated adhesives, the connections made with this adhesive failed under the lowest value of peel force of all the investigated polymers. This phenomena might be caused by the high value of stiffness modulus for the Sika ${ }^{\circledR P T}$ polymer - this results in local peel stress concentrations and failure in the adhesion zone.
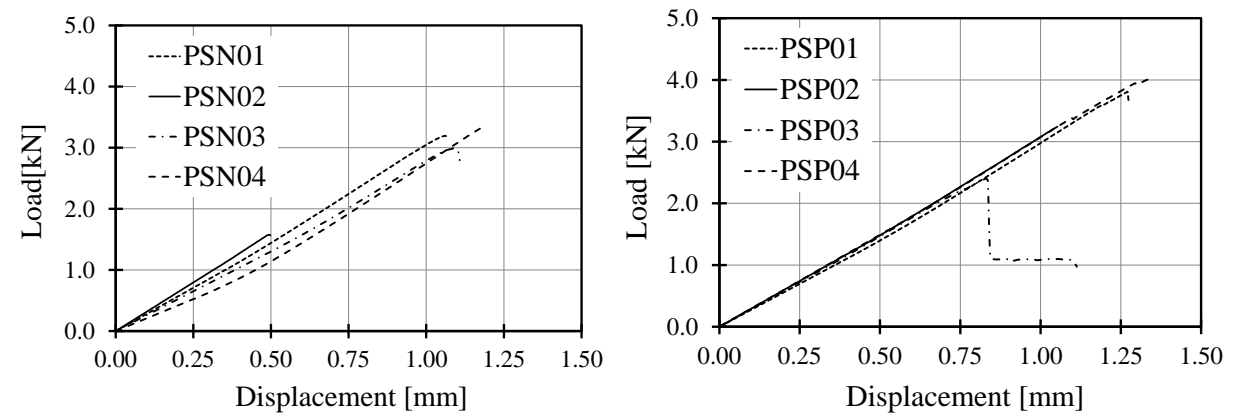

Fig. 7. The result of pull-off tests for elements bonded with the Sika ${ }^{\circledR P S}$ polymer for the non-primed timber (left) and primed timber (right) surfaces 
On the basis of the pull-off testing of joints, it can be noted that the investigated polyurethane adhesives present very strong adhesion to both glass and timber. It should be noted that detached wood grains were present on the adhesive surface for all experimental elements with which the destruction zone was in the adhesive-timber zone. The joint peel capacity is then comparable with, or even greater than, the tensile strength of the timber perpendicular to the grains. Nevertheless, the Sika ${ }^{\circledR P T}$ polymer seems a bit too stiff for combining with glass because of its vulnerability to rupture joint failure. One of the most significant findings of the research is the fact that Sika ${ }^{\circledR P S}$ adhesive, with the appropriate preparation of glass surface, provides the greatest peel capacity within all investigated adhesives in this paper. It can be assumed that peel stresses in the joint are much more uniformly distributed for the Sika ${ }^{\circledR P S}$ polymer, as indicated by the radial arrangement of the failure cracks in the glass (Fig. 8).
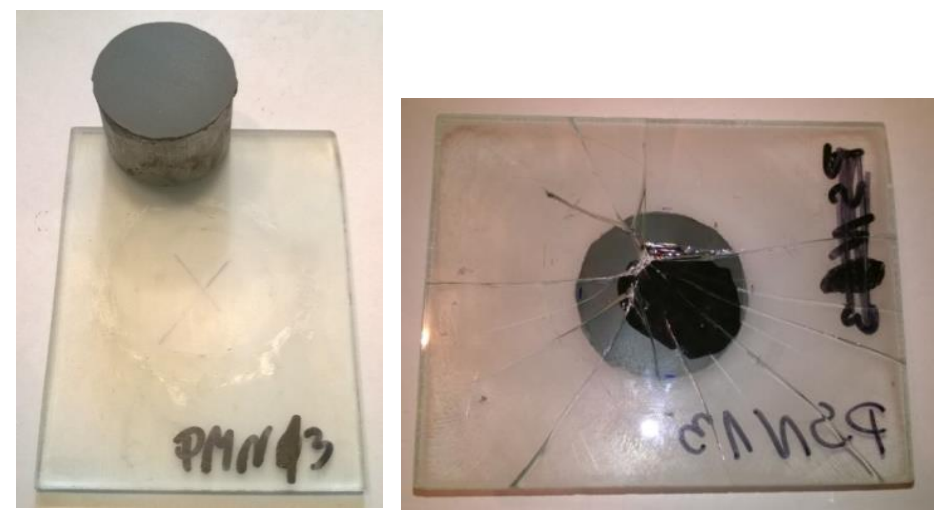

Fig. 8. Failure in glass-adhesive zone (left) and glass failure on bending (right)

\section{SHEAR TEST INVESTIGATION OF THE JOINT}

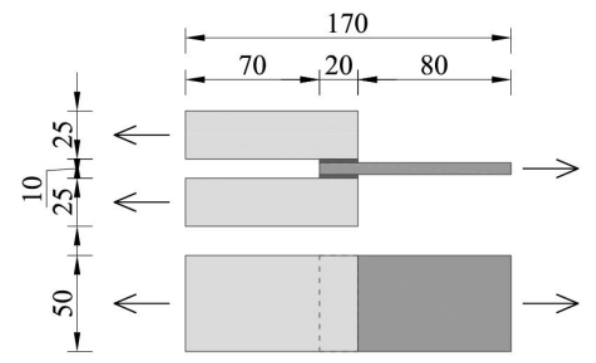

Fig. 9. Element for shear strength investigation of the joint

The experimental investigation was carried out on 7 timber-glass elements with dimensions of $50 \mathrm{~mm} \times 60 \mathrm{~mm} \times 170 \mathrm{~mm}$ (Fig. 9). All elements were investigated 
in quasi-static plane shear double lap joint tests. The timber and glass elements were made of the same materials as in the previous section, and the bonded glass surfaces were roughened by sandblasting them with corundum sand. The elements were bonded to each other with Sika ${ }^{\circledR P S}$ and Sika ${ }^{\circledR P M}$ adhesives, maintaining the $2 \mathrm{~mm}$-thick adhesive layer - the same thicknes as in the composite I-beams from section no 5. All bonded elements were primed with the dedicated Sika ${ }^{\circledR Z M}$ Primer for improving the adhesion force of the polyurethane adhesives to the bonded surfaces. The test was performed with a displacement rate of 0.25 $\mathrm{mm} / \mathrm{min}$, which was selected in accordance with the relevent literature [23, 30, $31,32]$.
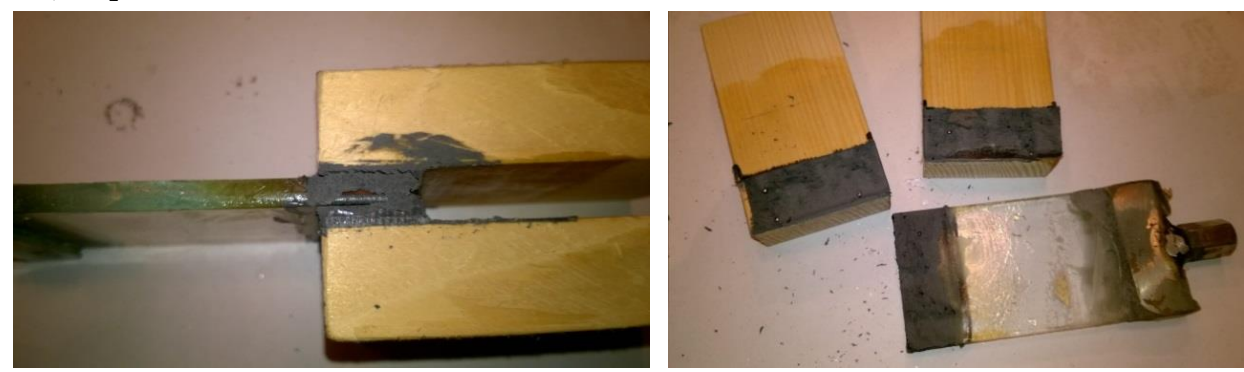

Fig. 10. Failed double lap joint (left), morphology of slide plane in adhesive layer (right)

For the evaluated mean values of the shear modulus of the lap joints, the stressstrain curves for the adhesive layer were drafted and compared with the curves obtained during the investigation (Fig. 11). It can be observed that the stress-strain curves for the Sika ${ }^{\circledR P M}$ polymer are significantly similarity. In the case of the Sika ${ }^{\circledR P S}$ polymer, a slightly higher modulus deviation from the average value can be reported.
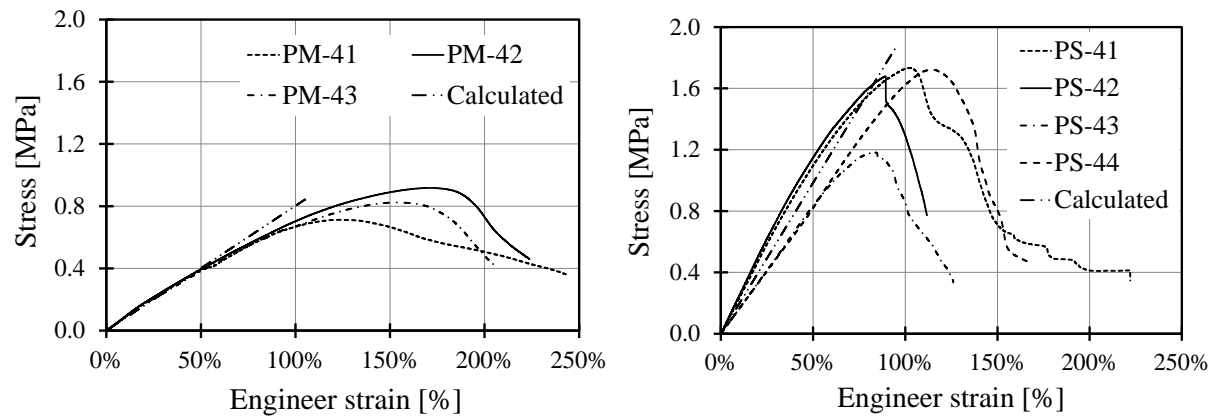

Fig. 11. Test results of double lap joint investigation for elements bonded with the Sika ${ }^{\circledR P M}$ polymer (left) and the Sika ${ }^{\circledR} P S$ polymer (right)

The conducted plane shear tests of timber-glass joints bonded with polyurethane adhesives support the conclusions from the pull-off tests regarding its very good adhesive features for both glass and timber surfaces. What is more, polyurethane 
adhesives used in these investigations present significant similarity of results in the load tests especially for the linear-elastic part of joint response.

All investigated elements failed with regard to their ductility. It can be concluded that the polyurethane adhesives in shear lap joints are a safe solution. Moreover, in all investigated elements, the failure energy reached a significant value. The final observation was that the failure plane appeared in the adhesive layer, the adhesion zones were free of any destruction in the case of all investigated elements (Fig. 10). The adhesive layer refers to the adhesive itself and the adhesion zone refers to the areas on the timber and/or glass to which the adhesive is applied.

It should be kept in mind, that the presented investigation of shear double lap joints includes the work of the entire connection - thus the adhesives, the bonded materials and the adhesion zone. That is why it should not be equated with the usual shear tests, which focuses only on the adhesive. The used adhesives provide a linear distribution of tensile stresses through the glass regardless of the rigidity of the material. This ensures a safe failure mode even at a higher connection stiffness - this is concluded from the lack of glass failure during the test (indicating no stress concentration in the glass pane). After initial observations, it can be assumed that the Sika ${ }^{\circledR P S}$ adhesive is the most appropriate choice for further composite I-beam investigations due to it having a greater rigidity than Sika ${ } P M$ adhesive, its good adhesion to jointed materials and high ductile failure mode.

\section{INVESTIGATION OF COMPOSITE I-BEAMS}

The cross section of the beams used during the investigation are shown in Fig. 12 with all dimensions. Three beams were prepared, all with dimensions of $3,100 \mathrm{~mm}$ x $220 \mathrm{~mm}$ x $70 \mathrm{~mm}$. Flanges were made from solid class C22 fir timber with cross sectional dimensions of $40 \mathrm{~mm} \times 70 \mathrm{~mm}$. The $17 \mathrm{~mm} \times 10 \mathrm{~mm}$ groove was made for the entire length of the flange for the glass web bonding. Timber for construction of flanges was carefully selected and chosen to be part of the heartwood as this provides dimensional stability at varying levels of humidity and has a lower concentration of knots.

As it was mentione in chapter 2, in previous studies, similar beams made from float glass (annealed), fully-tempered glass, single glass and heat-strengthened laminated glass were used - out of these, In the case of float glass, when the first crack appears, large shards of glass are maintained in the element and this results in further load bearing capacity (post-breakage) - tensile stresses at the position of the crack are further transferred to the flange). Heat-strengthened and fullytempered glass, despite their increased tensile strength relative to the float glass, fail due to the very rapid disintegrating into small pieces when the first crack in the element appears - this results in the complete decomposition of the bending 
element. Summing up all the above, it was concluded that float glass (annealed) is the best option for constructing such beams and it was decided to make the beam web with laminated float glass (annealed) on a film of PVB. The web consists of two panes, each with cross sectional dimensions of $3 \mathrm{~mm} \times 170 \mathrm{~mm}$, on double PVB film. The total cross sectional dimension of the web is $6.68 \mathrm{~mm} x$ $170 \mathrm{~mm}$. Moreover, in the case of glass panes bending around the 'stronger' axis, the appropriate preparation of edges by polishing according [33] is very important. The connection between the web and the flanges were made with a $2 \mathrm{~mm}$-thick Sika®PS polyurethane adhesive layer with very good adhesion to both glass and timber, resistance to changing temperatures, good shear stiffness, resistance to UV radiation and high levels of both, tensile and shear strengths.

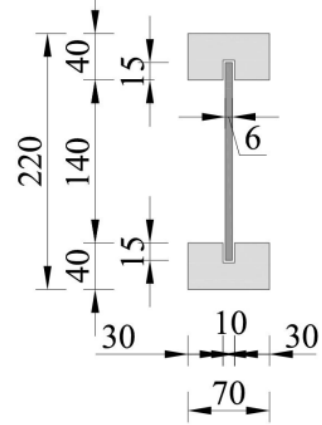

Fig. 12. The cross section of composite timber-glass I-beam used for the investigation

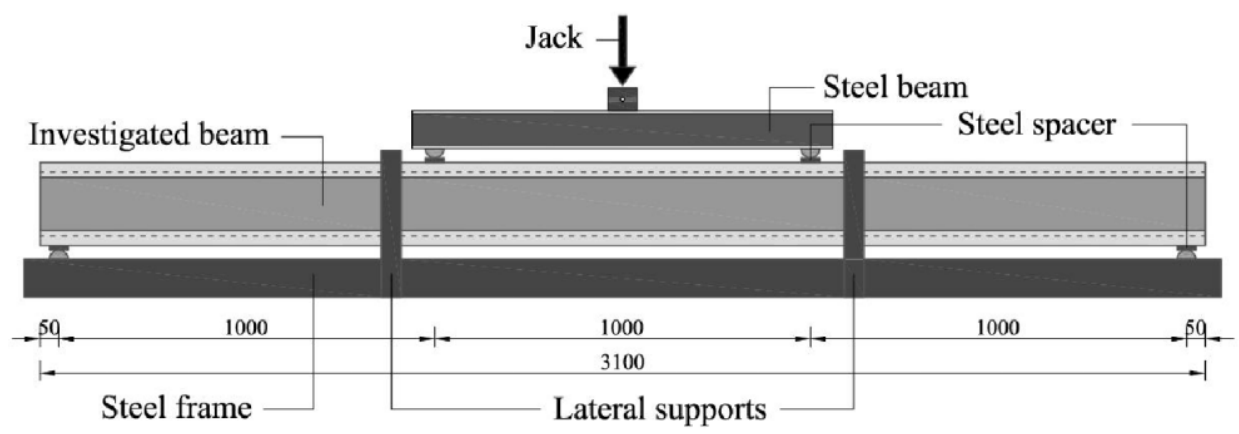

Fig. 13. Schematic of the test position for the beam bending tests

Four point quasi-static bending tests of CB-SL-1, SL-CB-2 and CB-SL-3 beams were carried out in the Laboratory of Materials and Structures at Cracow University of Technology. Figure 13 presents a schematic layout of the test stand. Strain gauges on the timber flanges were mouted in the middle of the beam span, one on the bottom and one on the top flange. Strain gauges on the glass web were mounted on both sides in the middle of the span (top and bottom) and at the load 
application points (top and bottom). Displacement gauges for the adhesive layer strain measurements were mouted on one side of the beam at both ends, top and the bottom (Fig. 14). The base for shear strains measurements equaled to $100 \mathrm{~mm}$. The selection of the points for the bond layer measurement deformations was dictated by the maximum values of shear stress, depending on the shear force distribution. In order to avoid lateral-torsional buckling of the beam during the test, additional lateral supports were positioned symmetrically on both sides of the points of the application of force (Fig. 13). The test was controlled with regard to displacement rate, which was $2 \mathrm{~mm} / \mathrm{min}$.

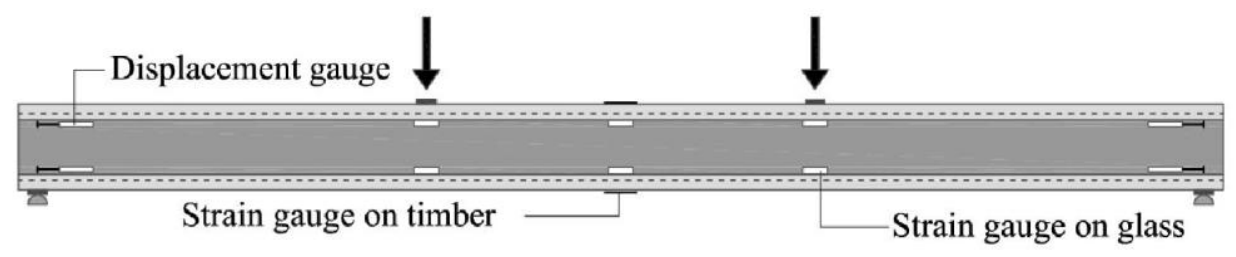

Fig. 14. Schematic of gauges distribution on the beam

All tested elements responded in an almost perfectly linear-elastic manner until the first crack appeared. After the first crack apperance, the jump on the forcedeflection graph can be seen, but after stabilisation and following the increase of load, the elements still respond in a linear-elastic manner until complete failure (Fig. 15). All three tested items failed as a result of the shear strength being exceeded in the adhesive bond layer near to the beam support (in places were the shear stress are the biggest).

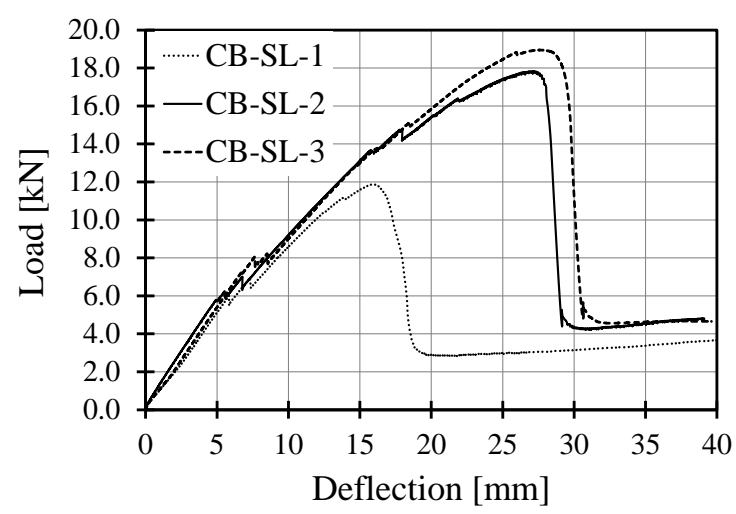

Fig. 15. Dependence of the mid-span deflection on the value of applied loading for all investigated beams

All investigated elements failed in a ductile manner which was signalled long before the fully loss of capacity. Even after the final destruction, ie. the loss of the ability to sustain a further increase of load, elements did not disintegrate. The 
tensioned flange was still able to keep all parts of the cracked web together, even for a $60 \mathrm{~mm}$ beam deflection (Fig. 16).

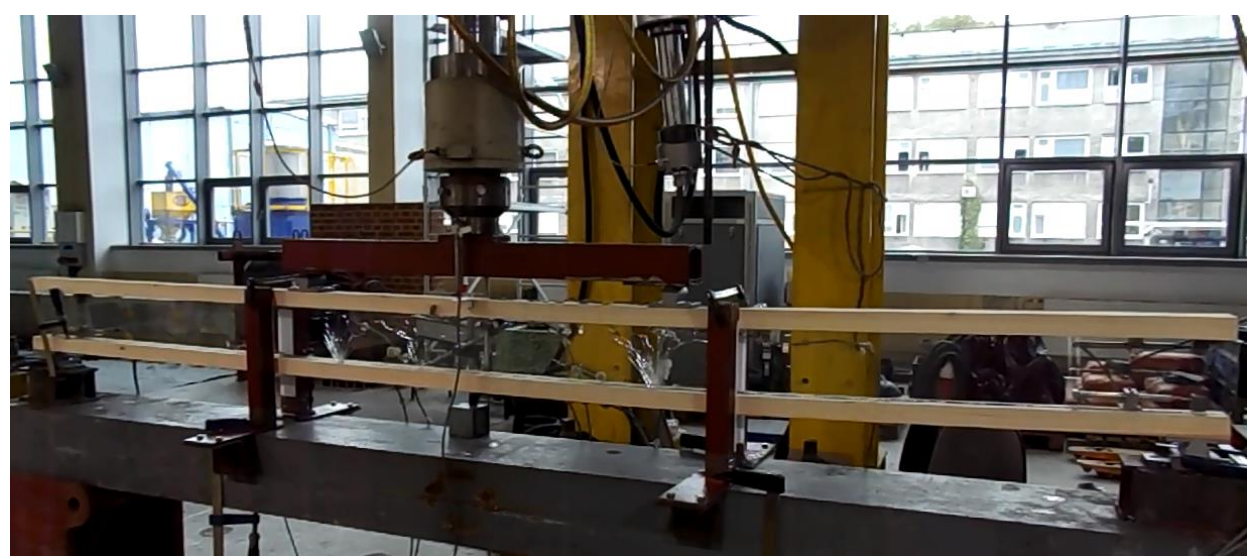

Fig. 16. Photo of failed composite timber-glass I-beam

\section{SUMMARY AND RESULTS DISCUSSION}

Despite the high deformability of the adhesive layer, wherein the strains reached levels of over $30 \%$ just before the final failure, it was the adhesive bond that failed in the case of all beams. Even after the final failure, ie. the loss of further load bearing ability, elements did not disintegrate. The tensioned flanges were still able to keep all parts of the cracked web together even for $60 \mathrm{~mm}$ deflection of the beam. The use of float glass (annealed) laminated on a PVB film had also a positive influence on the beam response during the post-breakage phase and caused the release of only a very few and small shards of glass.

Table 2. Comparison of bending stiffness of all investigated beams

\begin{tabular}{ccc} 
No & Element & $\begin{array}{c}\text { Bending stiffness } \\
{\left[\mathrm{MNm}^{2}\right]}\end{array}$ \\
\hline \hline 1 & CB-SL-1 & 0.972 \\
\hline 2 & CB-SL-2 & 1.099 \\
\hline 3 & CB-SL-3 & 1.030 \\
\hline \hline & Mean value & $\mathbf{1 . 0 3}$ \\
\hline & Standard deviation & $\mathbf{0 . 0 6 4}$ \\
\hline & $\mathbf{6 . 2 \%}$
\end{tabular}


Table 3. Values of loads causing the first web crack and the values of failure loading for the investigated beams

\begin{tabular}{ccccccc} 
No & Element & $\begin{array}{c}\text { Loading causing } \\
\text { the first crack } \\
{[\mathrm{kN}]}\end{array}$ & $\begin{array}{c}\text { Beam deflection } \\
\text { for the first crack } \\
{[\mathrm{mm}]}\end{array}$ & $\begin{array}{c}\text { Failure } \\
\text { loading } \\
{[\mathrm{kN}]}\end{array}$ & $\begin{array}{c}\text { Beam deflection } \\
\text { just before failure } \\
{[\mathrm{mm}]}\end{array}$ & $\begin{array}{c}\text { Post-critical } \\
\text { factor } \\
{[\%]}\end{array}$ \\
\hline \hline 1 & CB-SL-1 & 6.016 & 5.847 & 11.872 & 15.787 & 97.3 \\
\hline 2 & CB-SL-2 & 5.856 & 5.156 & 17.840 & 27.106 & 204.6 \\
\hline $3 \quad$ CB-SL-3 & 7.280 & 6.744 & 18.960 & 27.556 & 160.4 \\
\hline \hline Mean value & $\mathbf{6 . 3 8}$ & $\mathbf{5 . 9 2}$ & $\mathbf{1 6 . 2 2}$ & $\mathbf{2 3 . 4 8}$ & 154.1 \\
\hline $\begin{array}{c}\text { Standard } \\
\text { deviation }\end{array}$ & $\mathbf{0 . 7 8 0}$ & $\mathbf{0 . 7 9 6}$ & $\mathbf{3 . 8 1 0}$ & $\mathbf{6 . 6 6 9}$ & - \\
\hline $\begin{array}{c}\text { Coefficient of } \\
\text { variation }\end{array}$ & $\mathbf{1 2 . 2 \%}$ & $\mathbf{1 3 . 5 \%}$ & $\mathbf{2 3 . 5 \%}$ & $\mathbf{2 8 . 4 \%}$ & - \\
\hline
\end{tabular}

The composite timber-glass I-beams bonded with the Sika ${ }^{\circledR P S}$ polyurethane adhesive were characterised by their very high levels of consistency with regard to initial bending stiffness (Table 2) and the load level causing the first crack (Table 3). Furthermore, the investigated beams had significant post-breakage bending capacity which ranged from $97.3 \%$ to $204.6 \%$ of the first crack load. The achieved post-breakage bending capacity of elements perfectly corresponds with the research of other authors. In addition, it can be concluded that the use of Sika ${ }^{\circledR P S}$ polyurethane adhesive to bond timber-glass beams is reasonable, provided that a broader study of similar elements is carried out.

\section{ACKNOWLEDGMENT}

The research presented in this paper was carried out with funds granted by the Dean of the Faculty of Civil Engineering, Cracow University of Technology with the number L-1/369/2016/DS-M. Special thanks to FAKRO Sp. z o. o. from Nowy Sącz for providing glass elements for research and Sika Poland SA for providing polyurethane adhesives. Additional thanks to Antoni Rodacki and Bogusław Zając for their help in the element assembly process and the crew of Laboratory of Building Materials and Structures, Cracow University of Technology crew for their help in experimental investigations.

\section{REFERENCES}

1. Kreher K.: Tragverhalten und Bemessung von Holz-Glas-Verbundträgern unter Berücksichtigung der Eigenspannungen im Glas, $\mathrm{PhD}$ thesis, École Polytechnique Fédérale de Lausanne, Switzerland, 2004. 
2. Kreher K.: Load introduction with timber. Timber as reinforcement for glued composites (shear-walls, I-beams) structural safety and calculation-model, 9th World Conference on Timber Engineering, Portland 2006.

3. Hamm J.: Tragverhalten von Holz und Holzwerkstoffen im statischen Verbund mit Glas, PhD thesis, École Polytechnique Fédérale de Lausanne, Switzerland 2000.

4. Hamm J.: Development of timber-glass prefabricated structural elements, Innovative Wooden Structures and Bridges IABSE Conference 1, Lahti 2001, pp. 41-46.

5. Cruz P. and Pequeno J.: Timber-Glass Composite Beams: Mechanical Behaviour and Architectural Solutions, Proceedings of the Challenging Glass Conference, Delft 2008, pp. 439-449.

6. Blyberg L. et. al.: Glass, timber and adhesive joints - Innovative load bearing building components, Constr. Build. Mater., 2014, no 55, pp. 470-478.

7. Blyberg L. et. al.: Adhesive joints for structural timber/glass applications: Experimental testing and evaluation methods, International Journal of Adhesion \& Adhesives., 2012, no 35, pp. 76-87.

8. Blyberg L. i Serrano E.: Timber/Glass adhesively bonded I-beams, Lineaus University.

9. Kozłowski M., Serrano E., and Enquist B.: Experimental investigation on timber-glass composite I-beams, Challenging Glass \& COST Action TU905 Final Conference, London 2014.

10. Kozłowski M.: Experimental and numerical analysis of hybrid timber-glass beams, PhD thesis, Silesian University of Technology, Gliwice 2014.

11. Dorn M., Kozłowski M., and Serrano E.: Design approaches for timber-glass beams, Glass, facade, energy: Engineered Transparency International Conference at Glasstec: Conference on Glass, Glass Technology, Facade Engineering and Solar Energy, Dusseldorf, 2014, pp. 1-9.

12. Hulimka J. and Kozłowski M.: Mechanism of Failure and Post-Breakage Strength of Hybrid Timber-Glass Beams, 10th International Conference on New Trends in Statics and Dynamics of Building, Bratislava 2012.

13. Kozłowski M. and Hulimka J.: Load-bearing capacity of hybrid timber-glass beams, ACEE J., 2014, no 2, pp. 61-70.

14. Kozłowski M. and Hulimka J.: Mechanism of Failure and Post-Breakage Strength of Hybrid Timber-Glass Beams, Proceedings of the 10th International Conference on New Trends in Statics and Dynamics of Buildings, Bratislava 2012.

15. Premrov M., Zlatinek M., and Štrukelj A.: Experimental analysis of loadbearing timber-glass I-beam, Construction of Unique Buildings and Structures., 2014, no 4 (19), pp. 11-20.

16. Rodacki K.: Belki zespolone drewniano-szklane - przeglad zagadnienia, in 
Zagadnienia aktualne poruszane przez młodych naukowców, t. 2, Kraków, 2016, pp. 549-554.

17. Rodacki K. and Mieszczak M.: Obciążenia termiczne belek o szklanym środniku - przeglad, in V Ogólnopolska Konferencja Budowlana Studentów i Doktorantów EUROIŻYNIER 2015 - referaty, Kraków 2015.

18. Veer F. and Zuidema J.: The strength of glass, effect of edge quality, Faculty of Architecture, TU Delft.

19. Veer F., Zuidema J., and Bos F.: The strength and failure of glass in bending, Glass Processing Days, Tempere 2005.

20. Information sheet, Sika ${ }^{\circledR} P M$, Sika Poland Sp. z o. o., 2014

21. Information sheet, Sika ${ }^{\circledR P S}$, Sika Poland Sp. z o. o., 2014.

22. Information sheet, Sika ${ }^{\circledR P T}$, Sika Poland Sp. z o. o., 2014.

23. Kwiecień A.: Polimerowe złacza podatne $w$ konstrukcjach murowych $i$ betonowych, Kraków: Wydawnictwo PK 2012.

24. Zając B.: Doświadczalno analityczne określenie wytężenia polimerowej skleiny w belkach zespolonych, $\mathrm{PhD}$ thesis, Kraków, Politechnika Krakowska 2008.

25. Kuczma B.: Analiza statyczno-wytrzymatościowa zespolonych belek stalowobetonowych o podatnych tacznikach, $\mathrm{PhD}$ thesis, University of Zielona Góra, Zielona Góra, 2011.

26. Freytag B.: Glass-concrete composite technology, Structural Engineering International, $\mathrm{nr}$ 14(2), 2004.

27. PN-EN 338: 1999 Drewno konstrukcyjne - Klasy wytrzymałości, PKN 1999.

28. EN 572-1 Szkło w budownictwie - Podstawowe wyroby ze szkta sodowowapniowo-krzemianowego - Część 1: Definicje oraz ogólne wtaściwości fizyczne i mechaniczne, PKN 2012.

29. Information sheet, Sika®ZP Primer, Sika Poland Sp. z o. o., 2014.

30. Blyberg L. et al.: Adhesive joints for timber/glass applications - Part 1: Mechanical properties in shear and tension, SP Technical Research Institute of Sweden.

31. EN ISO 527-2: 2012 Tworzywa sztuczne - Oznaczenie właściwości mechanicznych przy statycznym rozciaganiu - Część 2: Warunki badań tworzyw sztucznych przeznaczonych do różnych technik formowania, PKN 2012.

32. EN ISO 527-1: 2012 Tworzywa sztuczne - Oznaczenie właściwości mechanicznych przy statycznym rozciaganiu - Część 1: Zasady ogólne, PKN 2012.

33. ISO 12543-1: 2011(E) Szklo w budownictwie - Szkto warstwowe i bezpieczne szkło warstwowe - Część 1: Definicja i opis elementów składowych, 2011. 


\section{NOŚNOŚĆ BELEK DREWNIANO-SZKLANYCH ZESPOLONYCH PRZY UDZIALE KLEJÓW POLIURETNAOWYCH}

\section{Streszczenie}

Artykuł poświęcony jest zagadnieniu dwuteowych belek zespolonych drewnianoszklanych, które stanowią ciekawą alternatywę dla nośnych belek stropów i stropodachów. Ideą belek drewniano-szklanych jest połączenie najlepszych parametrów obu tych materiałów przy maksymalizacji bezpieczeństwa ich użytkowania. Sztywne, wytrzymałe i kruche szkło za pomocą elastycznego kleju łączony jest $\mathrm{z}$ elastycznym i ciągliwym drewnem. Ze względu na znaczne różnice między łączonymi powierzchniami drewnianymi i szklanymi, na początku artykułu przedstawiono badania przyczepności różnych klejów do obu tych powierzchni. Po przeanalizowaniu kilku klejów poliuretanowych pod kątem zastosowania ich do łączenia drewna ze szkłem w belkach zespolonych wybrano dwa kleje o najlepszych parametrach, a następnie zbadano nośność połączenia wykonanego przy pomocy tych klejów w próbie prostego ścinania. Zespolone belki drewniano-szklane wykonano przy użyciu drewna jodłowego, szkła laminowanego typu float oraz kleju poliuretanowego prezentującego najlepszą współpracę zarówno $\mathrm{z}$ drewnem jak $\mathrm{i}$ ze szkłem. Belki zespolone zostały przebadane $\mathrm{w}$ próbie czteropunktowego zginania quasi-statycznego.

Słowa kluczowe belki drewniano-szklane, klej poliuretanowy, konstrukcje zespolone nowej generacji

Editor received the manuscript: 20.09 .2017 